\title{
Investigating CNTs in Lung Tissue with FIB-SEM
}

\author{
Købler, Carsten; Saber, A.T.; Vogel, U.B.; Qvortrup, K.; Mølhave, Kristian
}

Published in:

Microscopy and Microanalysis

Link to article, DOI:

$10.1017 /$ S1431927613006570

Publication date:

2013

Document Version

Publisher's PDF, also known as Version of record

Link back to DTU Orbit

Citation (APA):

Købler, C., Saber, A. T., Vogel, U. B., Qvortrup, K., \& Mølhave, K. (2013). Investigating CNTs in Lung Tissue with FIB-SEM. Microscopy and Microanalysis, 19(Suppl 2), 916-917.

https://doi.org/10.1017/S1431927613006570

\section{General rights}

Copyright and moral rights for the publications made accessible in the public portal are retained by the authors and/or other copyright owners and it is a condition of accessing publications that users recognise and abide by the legal requirements associated with these rights.

- Users may download and print one copy of any publication from the public portal for the purpose of private study or research.

- You may not further distribute the material or use it for any profit-making activity or commercial gain

- You may freely distribute the URL identifying the publication in the public portal

If you believe that this document breaches copyright please contact us providing details, and we will remove access to the work immediately and investigate your claim. 


\title{
Investigating CNTs in Lung Tissue with FIB-SEM
}

\author{
C. Købler ${ }^{1,2}$, A.T. Saber ${ }^{3}$, U.B. Vogel $^{3}$, K. Qvortrup ${ }^{4}$ and K. Mølhave ${ }^{1}$ \\ 1. Technical University of Denmark, DTU Nanotech, Kgs. Lyngby, Denmark \\ 2. Technical University of Denmark, DTU CEN, Kgs. Lyngby, Denmark \\ 3. National Research Centre for the Working Environment, Copenhagen, Denmark \\ 4. University of Copenhagen, CFIM, Copenhagen, Denmark
}

An increasing interest in carbon nanotubes (CNTs) in both industry and research is leading to an intensified toxicological investigation of how CNTs affect living organisms [1]. High resolution electron microscopy images of CNTs in cell culture and tissue samples would aide in improving our understanding of their modes of action [1]. Typically this is obtained by preparing the sample for transmission electron microscopy (TEM) by resin embedding and subsequent ultramicrotome sectioning [2]. Thin sectioning of biological samples containing hard materials, such as CNTs, is known to create artefacts [3]. Instead of the diamond knife cutting through the hard CNTs, they can be dragged or dislodged from the sample [3]. This is generally a major problem as the induced artefacts obscure the actual nature of the sample. To circumvent this challenge a focused ion beam (FIB) in a scanning electron microscope (SEM) can be used. The FIB-SEM has the benefit of using an ion beam source which is able to mill through the CNTs without dislodging them. However, a major issue with using the FIB-SEM is that it is a very time consuming if large volumes are to be investigated. Hence, the ability to pin-point areas of interest with relevant tissue features and CNTs is of great importance. Here we present a method for localising otherwise sporadically placed CNTs in lung tissue via CNT protrusions in the embedded block surface after ultramicrotomy, and show FIB-SEM images of CNTs interface with lung tissue.

Mice lungs were intratracheally instilled with two different multiwalled CNTs. The average dimensions for the two CNTs are: 1) $800 \mathrm{~nm}$ long and $10 \mathrm{~nm}$ width from Nanocyl, and 2) $4 \mu \mathrm{m}$ long and $70 \mathrm{~nm}$ width from IoLiTec. After 24 hours the animals were euthanized, the lungs fixed in glutaraldehyde and a standard embedding procedure in Epon followed [4]. The embedded sample was sectioned which lead to described artefact such as scratches and holes as documented by the TEM images (cf. Figure 1 B-C). These artefacts could then be used to locate areas of interest on the Epon block surface in the SEM, as CNTs were found to protrude from the block (Figure $1 \mathrm{D}-\mathrm{F}$ ).

Of the two different CNT types studied, the long thick CNTs (IoLiTec) sometimes left $1 / 2 \mu \mathrm{m}$ long CNTs protruding from the surface, while the thinner and shorter CNTs (Nanocyl) protrusions were typically less than $200 \mathrm{~nm}$ (data not shown). In both cases it was possible to localise CNTs in the lung tissue via CNT protruding from the block with standard SEM imaging. Using backscattered electron detection, both the CNT protrusions and the lung tissue could be imaged (Figure $1 \mathrm{D}$ ), making it possible to localize areas where CNTs were interacting with tissue, thereby saving time looking for CNTs close to lung cells with the FIB-SEM. Relevant areas of the sample can thereby easily be identified and FIBSEM imaging can be performed as demonstrated (Figure 2). This localisation method can be an important step on the way of understanding exactly how CNTs interact in-vivo, as one can limit imaging to relevant sites and obtain 3D images if needed thereby complementing the standard high resolution 2D TEM images. 
References:

[1] H.C. Nerl et al, Nanomedicine 6(2011) 849-865.

[2] K.T. Al-Jamal et al, Nanoscale 3(2011) 2627-2635.

[3] A.B. Maunsbach in "Biomedical electron microscopy", 15ed. Academic Press, (San Diego).

[4] R. Wierzbicki et al, PLoS ONE 8(2013) e53307.

[5] Work was supported by 'Danish Centre for Nanosafety' (20110092173/3) from the Danish Working Environment Research Foundation and FP7-NanoSustain (247989).
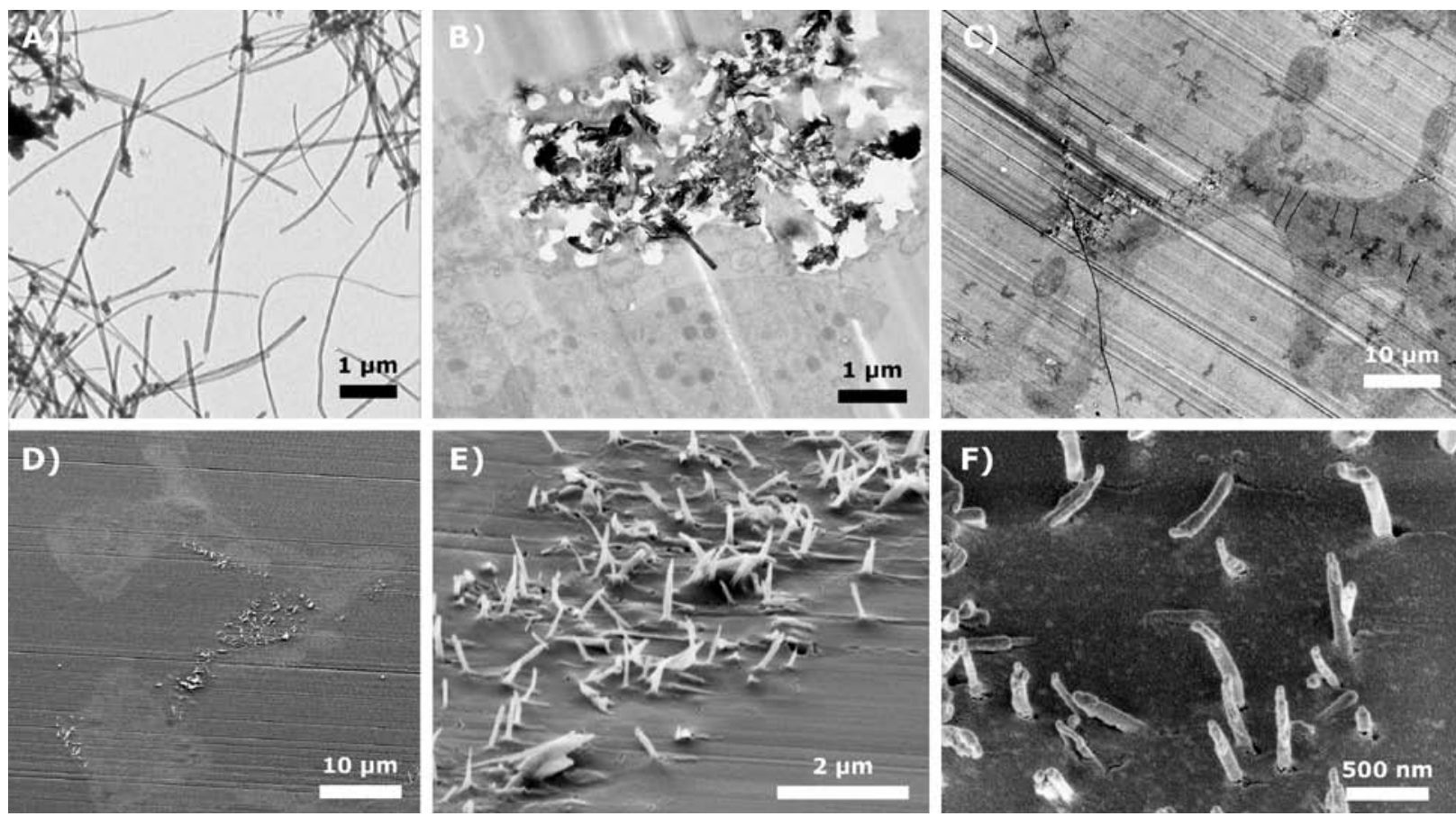

Figure 1. A) TEM image of pure CNTs on formwar TEM grid. B-C) TEM images of embedded mice lung tissue with CNTs causing massive microtoming damages, such as scratches and holes in the film. D-F) SEM images of the microtomed block, showing CNTs sticking up from the block. Images all show IoLiTec CNTs with lengths of 5-15 $\mu \mathrm{m}$ and a mean thickness of $70 \mathrm{~nm}$.
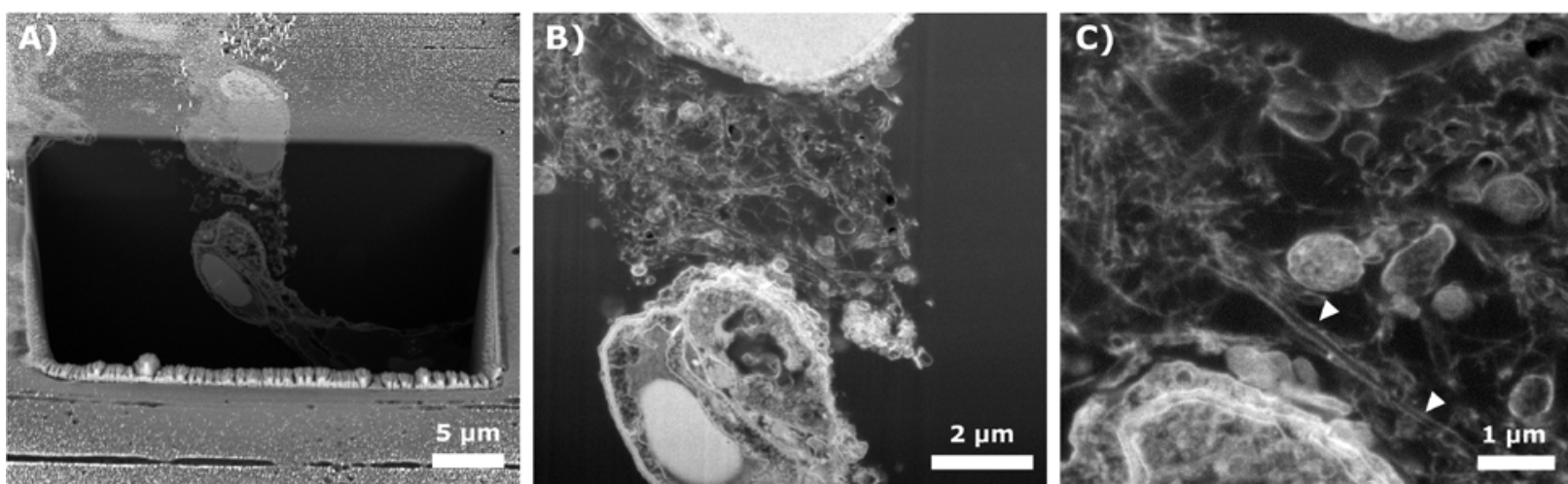

Figure 2. FIB-SEM of the IoLiTec CNTs in lung tissue. A) Image of ion beam milled trench in an area of interest with CNTs. B-C) Backscatter images of CNTs in between two cells. C) High magnification image where the tubular structures of the CNTs can be seen (white arrows). 